\title{
China's Outward Foreign Direct Investment and Domestic Investment: An Industrial Level Analysis
}

\author{
Kefei You*, Offiong Helen Solomon†
}

December 2014

\begin{abstract}
In the past decade, China's outward foreign direct investment (FDI) has increased significantly. On the other hand, the Chinese economic growth model is heavily reliant on domestic investment. Our study examines the important issue of how China's domestic investment responds to its FDI outflows. We investigate this issue analyzing, for the first time, China's domestic investment at industrial level. We specifically account for the factor of government support given the significant role played by the state in the Chinese economy. Using industrial level data, we further evaluate whether domestic investment reacts to outward FDI differently between statedominated industries and those that are not state-dominated. Our study adopts an accelerator model in which the system-Generalized Method of Moments (GMM) is used to construct our estimates. Our empirical results suggest that domestic investment responds positively to outward FDI in China. Furthermore, the FDI outflows influence domestic investment differently according to the level of government support for individual industries. Such influence is much stronger in state-dominated industries than in those that are not state-dominated.
\end{abstract}

JEL Classification: E22, F21, O16, P23

Keywords: Outward Foreign Direct Investment, China, Industry, Government, GMM

* (Corresponding author) Centre for International Capital Markets, London Metropolitan University, 84 Moorgate, London EC2M 6SQ, UK. Email: k.you@londonmet.ac.uk. Phone: +44 (0)20 73201520. † Department of Strategic Management and Marketing, De Montfort University, Hugh Aston Building, The Newarke, Leicester, LE2 7BQ, UK. Email: helen.solomon@dmu.ac.uk. Phone: +44 (0)116 2577438. 


\section{Introduction}

Since its reform and opening up policy was implemented in 1978, China has been attracting foreign direct investment (FDI) from the rest of the world and has become one of the world's largest FDI destinations. In the past decade, however, a new trend has emerged: there has been a dramatic increase in China's outward FDI (OFDI), especially after the national policy of encouraging domestic investment to "go out” in 1999 (see Table 1). In 2013, China ranked as the world's third largest source of FDI flows, after only the US and Japan.

Table 1. China's OFDI and domestic investment (2003-2013)

\begin{tabular}{llccc}
\hline Year & $\begin{array}{l}\text { China OFDI } \\
(10,000 \text { USD) }\end{array}$ & China OFDI/GDP (\%) & $\begin{array}{c}\text { Domestic investment } \\
(10,000 \text { USD) }\end{array}$ & $\begin{array}{c}\text { Domestic } \\
\text { investment/GDP (\%) }\end{array}$ \\
\hline 2003 & 285,465 & 0.17 & $67,134,227$ & 40.91 \\
2004 & 549,799 & 0.28 & $85,148,000$ & 44.08 \\
2005 & $1,226,117$ & 0.54 & $107,256,428$ & 48.00 \\
2006 & $1,763,397$ & 0.65 & $134,279,820$ & 50.85 \\
2007 & $2,650,609$ & 0.76 & $172,262,224$ & 51.66 \\
2008 & $5,590,717$ & 1.24 & $227,285,639$ & 55.03 \\
2009 & $5,652,899$ & 1.13 & $323,392,032$ & 65.88 \\
2010 & $6,881,131$ & 1.16 & $407,146,831$ & 69.27 \\
2011 & $7,465,404$ & 1.02 & $460,129,995$ & 65.84 \\
2012 & $8,780,353$ & 1.07 & $580,130,984$ & 72.20 \\
2013 & $10,784,000$ & 1.17 & $689,546,772$ & 76.52 \\
\hline
\end{tabular}

Note: China's OFDI data are collected from the Statistical Bulletin of China's Outward Foreign Direct Investment (2003-2013) (Ministry of Commerce). GDP and domestic investment data are collected from China Statistical Yearbook (various years).

The Chinese growth model relies heavily on the accumulation of domestic investment (Lee et al., 2013). Naturally, an important question relevant to policy makers is that of how China's domestic investment responds to this rising OFDI. Various theories have been developed by researchers explaining the possible influence of OFDI on domestic investment. For instance, overseas investment may direct scarce financial resources abroad and is thus likely to reduce concurrent domestic investment (Stevens and Lipsey, 1992). On the other hand, as explained by Desai et al. (2005), when firms combine home with foreign production, 
the production costs may be reduced and hence the return to domestic production increased. Thus OFDI would stimulate domestic investment. However, more recent studies (e.g. Hejazi and Pauly, 2003; Arndt et al., 2007; Al-Sadig, 2013) suggest that the combination of home and foreign production may entail a variety of potential impacts by OFDI on domestic investment, depending on the motives for the former. Referring to the four OFDI motives identified by Dunning (1993) (resource-seeking, market-seeking, efficiency-seeking and strategic asset-seeking), they point out that OFDI could influence domestic investment positively, negatively, or it might have no effect at all? The question therefore is: does China's overseas investment crowd out or crowd in the domestic investment? If the latter is true, fast-growing OFDI implies even more domestic investment, making China's shift from an investment-led to a consumption-led growth model even more challenging. If the former is true, then China's OFDI would ease the pressure on domestic investment accumulation, acting as an additional stimulus to China's shift to a more consumption-dependent economy. Thus, given China's fast-growing OFDI and its current domestic investment-reliant growth model, a careful investigation of the impact of OFDI on domestic investment is warranted.

For developing countries, the impact of OFDI on domestic investment has been empirically analyzed by many studies. Recent reviews by Arndt et al. (2007) and Al-Sadig (2013) suggest that these studies employ either aggregated macro-level data or firm-level data, and that the results are inconclusive, their impact being variously positive, negative and even zero.

Little attention has been paid to such impact on developing as opposed to developed countries, despite the rising importance of the former as an increasingly important source of FDI. By comparing Thai OFDI and domestic investment for the period 1978-2011, Sermcheep (2013) finds no evidence of a negative relationship between them. Kim (2000) provides a similar comparison regarding Korea for 1978-1995 and reaches the same 
conclusion. For Malaysia, Goh and Wong (2012) use bounds test and find a relative small negative impact of OFDI on domestic investment during 1999-2010.

In the particular case of China, the world's largest developing-country FDI source, Hong and Sun (2006) trace the dynamics of China's overseas investment strategies in both areas of government policy and corporate entrepreneurship. When combined with Dunning's (1993) explanations linking OFDI's impact to the motives for investing abroad, their study helps one understand the impact of China's OFDI on domestic investment. The availability of official data on OFDI only from 2003 is partly responsible for the fact that there is, to our knowledge, only one empirical study (Choy et al., 2009) examining how OFDI influences direct investment in China. These authors analyze the impact of OFDI on domestic capital stock using provincial data covering the period 2004-2007. Using fixed effects, they find that the coefficient of OFDI is positive but statistically insignificant. Our study is therefore motivated not only by the importance and the relevance of how China's domestic investment responds to its OFDI, but also by the paucity of literature empirically examining this issue.

Specifically, our study contributes to the existing sparse literature on China in the following three ways. First, we investigate how China's domestic investment responds to OFDI through a fresh industrial perspective. The vast majority of previous studies are firmlevel or aggregate analyses. The former may only allow limited inference from a macroeconomic perspective and for policymakers (Arndt et al., 2007), while aggregate data would not support any meaningful examination since official statistics regarding China's OFDI is, as has been noted, only available from 2003. On the other hand, industry-level analysis for China could address both issues, and it is therefore advocated by recent studies for developed countries (e.g. Hajazi and Pauly, 2003; Braunerhjelm et al., 2005; Arndt et al., 2007). For the first time, therefore, our study adopts an industrial perspective to investigate the impact of OFDI on domestic investment in the particular case of China. 
The second way in which our study adds to the literature on the subject is that, despite the emergence of a market system, the legacy of significant governmental involvement in business affairs is still strong in developing nations such as China (Luo et al., 2010). For instance, both at firm level, Wang et al. (2012) find that the level of government ownership an important driver of China's OFDI and Amighini et al. (2012) find that government ownership affects the destinations of China's overseas investment. Our study therefore emphasizes the role of government ownership in each industry. More importantly, it examines how the level of government ownership influences the mechanisms through which OFDI affects domestic investment. Specifically, we use industrial-level data to incorporate government ownership in each industry as one important determinant of domestic investment; we further classify our sample industries according to the level of government ownership so as to evaluate whether the impact of OFDI on domestic investment varies by industry.

Thirdly, as pointed out by Al-Sadig (2013), estimating the impact of OFDI on domestic investment raises the familiar problem of endogeneity. The endogeneity of OFDI arises because factors such as domestic business conditions and home government policies that influence firms' overseas investment decisions may also affect the rate of domestic investment. Consequently, we apply the system Generalized Method of Moments (GMM) to estimate a modified version of the flexible accelerator model to deal with ODFI's possible endogeneity. The flexible accelerator model of capital accumulation assumes that businesses adjust net investment to reduce the gap between the desired stock of capital goods on the one hand and the existing stock of capital goods from the previous period on the other. The flexible accelerator model is the modern version of Jorgenson's (1963) simple accelerator model which assumes that capital just jumps. The role of net investment in bridging the gap between the desired and actual levels of capital stock respectively under the assumption of 
profit maximization and perfect competition originates from Jorgenson's (1996) neo-classical accelerator model.

The rest of the paper is organized as follows. Section 2 provides an overview of China's OFDI and domestic investment since 2003. Section 3 presents the theoretical considerations and links them to China. Section 4 discusses the empirical model. Section 5 describes the system GMM estimator. Section 6 is the data description, and Section 7 presents the results. Section 8 provides some further analysis. The final section is a conclusion that also presents some policy implications.

\section{An overview of China's OFDI, domestic investment and government ownership at industrial level}

China's OFDI has surged during the past decade (Table 1) to become the world's third largest source of OFDI flow in 2013. However, despite its absolute size, China's OFDI remains relatively small compared with its Gross Domestic Product (GDP). For instance, as shown in Table 1, the OFDI flows to GDP ratios are lower than $2 \%$ in the last ten years. On the other hand, domestic investment, measured by the ratio of total investment in fixed assets to GDP (see Al-Sadig, 2013, for a similar measurement) has also increased significantly. Table 1 shows that the ratio of domestic investment to GDP is rather large, especially compared with that of OFDI. Such large ratios further demonstrate the heavy reliance of Chinese economic growth on domestic investment instead of consumption. During 2003-2008, both OFDI and domestic investment have grown, both absolutely and relative to GDP. The growth in absolute size continued following the outbreak of the financial crisis at the end of 2008, although their sizes relative to GDP temporarily fell in 2011 (This also applies to the OFDI to GDP ratio for 2009).

We further analyze the industrial distribution of China's OFDI. China's overseas investment is distributed between 14 industries (Table 2). Of these, the three largest are 
leasing and business services, mining and the wholesale and retail trade; next come manufacturing, construction, and then transport, storage and post. 
Table 2. Distribution of China's outward FDI flow by industry (million USD) (2004-2013)

\begin{tabular}{|c|c|c|c|c|c|c|c|c|c|c|}
\hline Industries & 2004 & 2005 & 2006 & 2007 & 2008 & 2009 & 2010 & 2011 & 2012 & 2013 \\
\hline 1. Agriculture, Forestry, Animal Husbandry and Fishery & 288.7 & 105.4 & 185.0 & 271.7 & 171.8 & 342.8 & 534.0 & 797.8 & $1,461.4$ & $1,813.1$ \\
\hline 2. Mining & $1,800.2$ & $1,675.2$ & $8,539.5$ & $4,062.8$ & $5,823.5$ & $13,343.1$ & $5,714.9$ & $14,446.0$ & $13,543.8$ & $24,807.8$ \\
\hline 3. Manufacturing & 755.6 & $2,280.4$ & 906.6 & $2,126.5$ & $1,766.0$ & $2,241.0$ & 4,664.2 & $7,041.2$ & $8,667.4$ & $7,197.2$ \\
\hline 4. Production and supply of electricity, heat, gas and water & 78.5 & 7.7 & 118.7 & 151.4 & $1,313.5$ & 468.1 & $1,006.4$ & $1,875.4$ & $1,935.3$ & 680.4 \\
\hline 5. Construction & 48.0 & 81.7 & 33.2 & 329.4 & 733.0 & 360.2 & $1,628.3$ & $1,648.2$ & 3,245.4 & 4,364.3 \\
\hline 6. Transport, storage and post & 828.7 & 576.8 & $1,376.4$ & $4,065.5$ & $2,655.7$ & $2,067.5$ & $5,655.5$ & $2,563.9$ & 2,988.1 & 3,307.2 \\
\hline 7. Information transmission, computer services and software & 30.5 & 14.8 & 48.0 & 303.8 & 298.8 & 278.1 & 506.1 & 776.5 & $1,240.1$ & $1,400.9$ \\
\hline 8. Wholesale and retail trade & 799.7 & $2,260.1$ & $1,113.9$ & $6,604.2$ & $6,514.1$ & $6,135.8$ & $6,728.8$ & $10,324.1$ & $13,048.5$ & $14,646.8$ \\
\hline 9. Lodging and catering services & 2.0 & 7.6 & 2.5 & 9.6 & 29.5 & 74.9 & 218.2 & 116.9 & 136.6 & 82.2 \\
\hline 10. Real estate & 8.5 & 115.6 & 383.8 & 908.5 & 339.0 & 938.1 & $1,613.1$ & $6,070.5$ & $2,018.1$ & $3,952.5$ \\
\hline 11. Leasing and business services & 749.3 & $4,941.6$ & $4,521.7$ & $5,607.3$ & $21,717.2$ & $20,473.8$ & $30,280.7$ & $1,974.4$ & $26,740.8$ & $27,056.2$ \\
\hline $\begin{array}{l}\text { 12. Scientific research, technical services and geological } \\
\text { prospecting }\end{array}$ & 18.1 & 129.4 & 281.6 & 303.9 & 166.8 & 775.7 & $1,018.9$ & 706.6 & $1,478.5$ & $1,792.2$ \\
\hline 13. Services to households and other services & 88.4 & 62.8 & 111.5 & 76.2 & 165.4 & 167.7 & 321.1 & 328.6 & 890.4 & $1,129.2$ \\
\hline 14. Cultural, sports and entertainment & 1.0 & 0.1 & 0.8 & 5.1 & 21.8 & 19.8 & 186.5 & 105.0 & 196.3 & 310.9 \\
\hline
\end{tabular}

Note: Data are collected from the Statistical Bulletin of China's Outward Foreign Direct Investment. The Bulletin in fact reports 18 industries, the other 4 being water conservancy, environment and public facilities management; education; health, social services and social welfare; and public management and social organisations. They are not included here because the relevant data are not available for several years. 
Although the Chinese government has strongly pursued privatisation and has implemented structural reforms in order to increase ownership in private organizations, domestic investments are still heavily controlled by the state. The distinctive role played by the Chinese government in domestic investment is particularly evident, as it retains some level of ownership in many industries. Table 3 shows that the level of government ownership as measured by the ratio of fixed assets investment made by the central government to the total fixed asset investment has experienced a dramatic reduction in many industries since 2004. By 2013, the level of government ownership in sectors such as manufacturing and wholesale and retail trade have fallen to around $10 \%$. On the other hand, many other industries such as the production and supply of electricity, heat, gas and water, as well as transport, storage and post are still dominated by state ownership. Industries with higher government ownership often enjoy significant political and economic advantages, since strategically important factor resources are controlled by the state (Warner et al., 2004). Therefore, given the importance and variety of government ownership across industries, it would be interesting and informative to account explicitly for government ownership in the analysis of OFDI’s impact on domestic investment in China. 
Table 3. Level of government ownership by industry (2004-2013)

\begin{tabular}{|c|c|c|c|c|c|c|c|c|c|c|}
\hline Industries & 2004 & 2005 & 2006 & 2007 & 2008 & 2009 & 2010 & 2011 & 2012 & 2013 \\
\hline 1. Agriculture, forestry, animal husbandry and fishery & 68.1 & 65.2 & 61.8 & 56.5 & 49.4 & 50.6 & 46.1 & 32.3 & 29.0 & 28.4 \\
\hline 2. Mining & 83.8 & 74.6 & 70.4 & 65.8 & 63.2 & 58.2 & 54.8 & 48.5 & 45.8 & 46.5 \\
\hline 3. Manufacturing & 40.0 & 28.4 & 21.8 & 20.5 & 20.3 & 17.7 & 16.3 & 13.0 & 10.6 & 9.8 \\
\hline 4. Production and supply of electricity, heat, gas and water & 81.1 & 77.7 & 77.8 & 78.0 & 77.8 & 79.3 & 76.3 & 71.7 & 70.1 & 68.0 \\
\hline 5. Construction & 69.6 & 57.4 & 45.6 & 50.0 & 55.6 & 55.5 & 58.0 & 56.5 & 58.3 & 58.2 \\
\hline 6. Transport, storage and post & 93.5 & 91.2 & 90.4 & 88.8 & 87.9 & 88.5 & 87.2 & 83.1 & 80.0 & 76.9 \\
\hline 7. Information transmission, computer services and software & 79.2 & 76.4 & 66.6 & 65.3 & 62.2 & 72.4 & 69.4 & 63.1 & 59.6 & 55.9 \\
\hline 8. Wholesale and retail trade & 33.0 & 21.5 & 17.1 & 15.9 & 14.6 & 13.5 & 12.6 & 10.7 & 12.2 & 11.5 \\
\hline 9. Lodging and catering services & 28.3 & 18.5 & 17.5 & 18.4 & 16.1 & 15.0 & 14.0 & 13.3 & 13.6 & 12.9 \\
\hline 10. Real estate & 22.4 & 18.3 & 18.9 & 17.5 & 17.5 & 20.3 & 20.3 & 20.4 & 23.2 & 23.4 \\
\hline 11. Leasing and business services & 53.4 & 44.7 & 46.2 & 51.3 & 46.4 & 51.3 & 49.5 & 39.0 & 34.6 & 29.5 \\
\hline $\begin{array}{l}\text { 12. Scientific research, technical services and geological } \\
\text { prospecting }\end{array}$ & 86.1 & 84.0 & 77.6 & 73.2 & 65.6 & 66.6 & 63.2 & 52.4 & 49.0 & 38.7 \\
\hline 13. Services to households and other services & 45.6 & 44.6 & 25.4 & 28.5 & 20.6 & 27.3 & 34.3 & 31.7 & 35.4 & 29.5 \\
\hline 14. Cultural, sports and entertainment & 77.2 & 72.2 & 69.4 & 70.5 & 65.7 & 58.5 & 56.5 & 48.6 & 47.4 & 45.4 \\
\hline
\end{tabular}

Note: Government ownership is measured as the ratio (\%) of fixed assets investment made by the central government to the total fixed asset investment. Data are collected from China Statistical Yearbook (various issues). 


\section{Theoretical considerations and their application to China}

The impact of OFDI on domestic investment is not a straightforward issue. Generally speaking, there are two mechanisms through which OFDI could affect the home country's domestic investment (Stevens and Lipsey, 1992). The first is through domestic financial markets. OFDI implies capital flows to host countries, which in turn means that a part of private domestic savings is shifted from home to foreign countries. Given an imperfect financial market and the scarcity of financial resources, domestic firms would have less financial liquidity available in domestic financial markets to fund their new domestic investment activities. This negative impact of OFDI on domestic investment would be particularly strong if the capital outflows are financed internally and if capital is scarce. However, in countries where savings are abundant and/or where OFDI is financed through sources other than domestic savings, this negative impact may not be evident.

The second mechanism operates when firms affect product markets by shifting production abroad. Normally, the combination of home with foreign production would reduce cost and raise the return to domestic production, thus making it likely to increase domestic investment (e.g. Desai et al., 2005). However, as pointed out by recent studies (e.g. Hejazi and Pauly, 2003; Arndt et al., 2007; Al-Sadig, 2013), how OFDI in the form of the shifting of production abroad affects domestic investment depends largely on the motives for such overseas investment. The four motives of resource-seeking, market-seeking, efficiencyseeking and strategic asset-seeking identified by Dunning (1993) have since been widely referred to in the existing literature to explain the phenomenon of OFDI.

The first motive, resource-seeking, corresponds to overseas investment that seeks physical resources, plentiful supplies of cheap and well-motivated unskilled or semi-skilled labor, and technological capability, management or marketing expertise and organization skills. Cost minimization and security of resource supply are the main driver for this type of 
OFDI. The second motive aims at supplying the local market, or markets in adjacent territories. Such international investment may represent firms’ deeper involvement following success in exporting, or the expansion of a firm into a wholly new market. The third motive refers to firms' frequent attempts to increase their cost efficiency by transferring production, totally or in part, to locations with lower costs for inputs such as labor. It also includes investment aimed at rationalizing the operations of existing firms in the form of exploitation of comparative advantages in adjacent territories, or to exploit economies of scale and scope across borders. The strategic asset-seeking OFDI aims to obtain strategic assets, tangible or intangible, that may be critical to firms’ long-term strategies but are not available at home. This type of international investment acts as a vehicle for firms to build the ownership advantage that will support their long-term expansion at home and abroad, or simply to aim to weaken the competitive position of its competitors.

These four alternative motives underlying OFDI would imply that overseas investment could have a variety of impacts on domestic capital formation. Resource-seeking OFDI, especially of the natural resource-seeking type, provides secured supplies of resources at relatively low cost, which in turn could facilitate domestic production and stimulate domestic investment. The positive impact of this type of OFDI on domestic capital formation would be particularly strong in countries with large natural resource consumption needs.

If market-seeking OFDI replaces exports or shifts domestic production abroad, it is likely to reduce domestic investment. However, it is worth pointing out that such OFDI may at the same time promote the exports of intermediate products from home to host countries. The net effect of such OFDI on domestic investment is therefore unclear (Hajazi and Pauly, 2003). If market-seeking OFDI does not replace exports or reduce domestic production, then it is likely to have little effect on domestic investment or even stimulate domestic investment via exports of intermediate goods. The net effect can thus be positive, neutral or negative. 
Efficiency-seeking FDI is intended to take advantage of various factor endowments, cultures, institutional arrangements, economic systems and policies, and market structures by concentrating production in a limited number of locations to supply multiple markets (Dunning, 1993). Whilst this type of overseas investment may shift production from home to host markets, and hence discourage domestic investment, it may also lead to exports of intermediate products to host markets in order to facilitate the production of the end product, thereby stimulating domestic investment (Hajazi and Pauly, 2003). The net effect is again unclear.

Strategic asset-seeking OFDI helps firms build up their ownership advantages at home and abroad $^{1}$. As discussed by Al-Sadig (2013), such ownership advantages may help firms' long term expansion at home and abroad, and thus stimulate domestic investment. The positive impact strategic asset-seeking OFDI has on domestic investment is mainly generated by new activities undertaken by domestic firms pursuant to the strengthening of firms' ownership advantages at home. It can also be generated by exporting intermediate products to host markets so as to facilitate the production of the end products.

Therefore, above theoretical explanations suggest that the effect of OFDI on domestic capital formation can be negative, neutral or positive, depending on the characteristics of each home country’s economy and of firms' underlying motives for overseas investment.

In the case of China, and in relation to the first mechanism by which OFDI affects domestic investment (i.e. via financial markets), its savings ratio is the highest of all the major economies ${ }^{2}$, which has enabled China to substantially boost its domestic investment.

\footnotetext{
${ }^{1}$ Traditional internationalisation theory asserts that firms must possess some ownership advantages as a basis from which to overcome intrinsic disadvantages when competing in a foreign market (Buckley and Ghauri, 1999). By contrast, Chinese firms' overseas expansion is actually a means for their firms to seek strategic assets in order to build up their competitive advantages or to offset their competitive disadvantages (Child and Rodriguez, 2005).

${ }^{2}$ For instance, according to the World Bank's figures for net national savings as a percentage of gross national income, China's savings ratio in 2012 was 38.9\%, higher than any other major world economy, and one of the highest in the world (second only to Algeria).
} 
Furthermore, China's gross domestic savings levels exceed its domestic investment levels, which have made China a large net global lender (Morrison, 2014). In addition, in the past decade, the huge amount of foreign exchange (FX) reserves accumulated from trade surplus have granted Chinese firms, especially large State Owned Enterprises (SOEs), the "fire power" to invest abroad. A large proportion of China overseas investment is thus directly financed by FX reserves (Wu, 2008) and does not drain the domestic savings pool. China's abundant savings and the fact that its FX reserves serve as alternative sources of funding therefore implies that China's OFDI is not likely to have a negative impact on its domestic capital formation through its domestic financial markets.

Regarding the second mechanism, which featuring product markets, a simple prediction based on cost reduction through the combination of domestic and foreign production would be that OFDI would have a positive effect on domestic investment in China. However, once we look further into the motives for China's overseas investment, the direction of that impact maybe less clear, especially given that various motives have been identified by previous empirical studies on China’s OFDI.

Cheung and Qian (2009) investigate the host country determinants of China’s OFDI, finding that it is driven by both market-seeking and resources-seeking motives. Also empirically analyzing host country determinants of Chinese OFDI, Amighini et al. (2011) use data disaggregated by three industries (manufacturing, resource intensive, and services industries) during period 2003-2008. They conclude that manufacturing is attracted by market-seeking motives, that resource-seeking is an important motive for resource-related sectors, and that the strategic asset-seeking motive applies to both manufacturing and services. With the same purpose and in a more recent study, Amighini et al. (2012) classify China's OFDI by ownership - that is, whether they are private firms or SOEs. Their empirical 
findings suggest that private firms are attracted by market-seeking and strategic asset-seeking motives, while SOEs are natural resource and strategic asset seekers ${ }^{3}$.

These studies provide valuable information regarding the motives for Chinese firms' international expansion, despite their focus being on the host country determinants of China's OFDI rather than on the impact of OFDI on domestic investment. It is the aim of our study to link these motives to the direction in which domestic investment in China responds to its OFDI. More importantly, the latter two studies confirm that employing industrial-level analysis and accounting for the role of government ownership, which our study does, would provide much more detailed and valuable information than simply using aggregate data. For instance, in China, industries dominated by the state often have a stronger resource-seeking motive than ones that are not, especially given China's soaring demand for natural resources. As explained above, the resource-seeking motive implies OFDI's positive impact on domestic investment, which is why we would expect OFDI in state-dominated industries to have a stronger positive impact on domestic investment than non-state-dominated ones would.

\section{The model}

In this section we detail the empirical model. Following Al-Sadig (2013), we assume that the level of domestic investment (DI) depends on the level of DI in the previous year, on OFDI, on inward FDI (IFDI) and on a list of control variables that captures the economic conditions in China (Equation (1)). It is essential to point out that, given the vital yet varied role of government support at industrial level discussed in Section 2, we include government support (GS) as an important determinant of China’s domestic investment.

$$
D I_{i, t}=\alpha_{0}+\alpha_{1} D I_{i, t-1}+\alpha_{2} O F D I_{i, t}+\alpha_{3} I F D I_{i, t}+\alpha_{4} G S_{i, t}+x_{i, t}^{\prime} \beta+\varepsilon_{i, t} \ldots
$$

\footnotetext{
${ }^{3}$ Cheung and Qian (2008) explain that although the typology of four motives by Dunning (1993) is used in some of the empirical studies on host country determinants of China's OFDI, the efficiency-seeking motive has so far been considered relatively unimportant for Chinese multinational companies because of the relatively low costs of domestic labour and other inputs (UNCTAD, 2006).
} 


$$
\varepsilon_{i, t}=\eta_{i}+v_{i, t}
$$

In Equation (1), Chinese industries and time are denoted by $i=1,2, \ldots N$ and $t=$ $1,2, \ldots T$ respectively. $\alpha$ denotes a column vector of $i$ cross sections, $x$ a column vector of control variables, and $\beta$ a row vector of parameters in the dynamic panel. Furthermore, $\varepsilon_{i, t}$ represents the disturbance term which consists of the unobserved individual specific effects $\left(\eta_{i}\right)$ and the remainder of the disturbances $v_{i, t}$ as shown in Equation (2).

The prime interest of our analysis is the direction and magnitude of the coefficients of OFDI and GS, although the effect of IFDI also provides useful information. The expected outcome of OFDI, namely negative, neutral or positive, is discussed in detail in Section 3. As previously mentioned, a higher level of GS implies a more favorable government policy and support for industrial-level domestic investment; a positive sign is thus expected for GS.

We would expect the lagged level of domestic investment to have a positive sign given that a good investment climate in the previous year should increase the level of domestic investment in the following one (Al-Sadig, 2013). In terms of IFDI, both focusing on China, Braunstein and Epstein (2002) find that IFDI crowds out DI, while Xu and Wang (2007) conclude the opposite.

As shown in Equation (1), we also include a set of control variables drawn from the relevant existing empirical literature. These control variables not only capture China's economic condition, but also act as a form of robustness check for our key results as well as helping control for endogeneity through their inclusion of OFDI and IFDI. The control variables, denoted by $x$ in Equation (1), include the growth rate of real Gross Industrial Product (RGIPG), domestic savings (SAVINGS), broad money supply (M2), real interest rate (R), trade openness (OPEN), financial development (FD) and country risk (CR).

RGIPG is the accelerate factor and is used to capture the level of economic activity (see Al-Sadig (2013) for a similar argument). A high level of economic activity encourages 
domestic investment (Blejer and Khan, 1984; Greene and Villanueva, 1991). From a business cycle point of view, a higher RGIPG is often associated with an expansion of DI during periods of boom in the business cycle (King and Plosser, 1984; Greenwood and Hercowitz, 1991; Kollintzas et al., 2011). Similarly, the three business cycle studies mentioned above also observe that a higher M2 is associated with more DI. Focusing on China, Zhang and Wan (2005) find that monetary expansion leads to an increase in fixed investment and vice versa. In terms of SAVINGS, Feldstein and Horioka (1980) famously demonstrate that savings and investment are highly positively correlated. For most developing countries, domestic savings act as the most important source of finance for domestic investment (e.g. Agènor, 2004); a similar conclusion is reached in the specific case of China (e.g. Yusuf, 1994). A higher real interest rate (R) increases the cost of borrowing or the cost of capital and therefore decreases domestic investment (Blanchard et al., 2010). Trade openness (OPENNESS) may positively affect domestic investment through technology and knowledge spillovers (Al-Sadig, 2013). Indeed, Jin (2004) uses provincial data for China to demonstrate that trade openness causes expansion in growth in the long term through technological improvement. Levine (2004) explains that an expansion in financial development (FD) contributes to the efficient channeling of private savings for investment in capital accumulation and production of goods and services. Finally, country risk measured by the ratio of net foreign assets to GDP takes into account a country's investment overseas net of investment by foreign investors in its domestic economy. Since the financial crisis in 2007, net foreign assets have increasingly been used as a signal of a country's financial problems. An increase in net foreign assets leads to a downgrading of sovereign bonds, which increases the risk of foreign investment in the host country (Temperton, 2012). We would therefore expect country risk to have a negative impact on the level of domestic investment.

The signs expected for all variables are shown in Appendix A. 
Appendix A. Variable measurement, data sources and expected signs

\begin{tabular}{|c|c|c|c|}
\hline Variables & Measure & Data source & Expected signs \\
\hline $\begin{array}{l}\text { Domestic investment (DI) } \\
\text { (industry-level) }\end{array}$ & Domestic investment of each industry divided by Gross Industrial Product (GIP) & CSY & Dependent variable \\
\hline $\begin{array}{l}\text { Previous domestic investment } \\
\text { (industry-level) }\end{array}$ & Lag of the domestic investment & CSY & + \\
\hline $\begin{array}{l}\text { Outward FDI (OFDI) } \\
\text { (industry-level) }\end{array}$ & Outward FDI of each industry divided by GIP & SBCOFDI, CSY, IFS & +/- or neutral \\
\hline $\begin{array}{l}\text { Inward FDI (IFDI) } \\
\text { (industry-level) }\end{array}$ & Inward FDI of each industry divided by GIP & CSY & $+/-$ \\
\hline $\begin{array}{l}\text { Government support (GS) } \\
\text { (industry-level) }\end{array}$ & $\begin{array}{l}\text { Fixed assets investment made by the central government divided by total fixed } \\
\text { asset investments }\end{array}$ & CSY & + \\
\hline $\begin{array}{l}\text { Growth rates (RGIPG) } \\
\text { (industry-level) }\end{array}$ & Growth rate of real (GIP deflator adjusted) GIP & CSY & + \\
\hline Savings (SAVINGS) & Household savings divided by Gross Domestic Product (GDP) & CSY & + \\
\hline Openness (OPENNESS) & Sum of exports and imports divided by GDP & CSY & + \\
\hline Supply of M2 (M2) & Supply of M2 & CSY & + \\
\hline Real interest rate $(\mathrm{R})$ & Real (consumer price index (CPI)-based inflation-adjusted) discount rate & IFS & - \\
\hline Financial development (FD) & Domestic credit divided by GDP & IFS & + \\
\hline Country risk (CR) & Net foreign assets divided by GDP & IFS & - \\
\hline
\end{tabular}




\section{Estimation method - system GMM}

As mentioned earlier, we employ the system Generalized Method of Moments (GMM) (twostep) estimator developed by Arellano and Bover (1995) and Blundell and Bond (1988) for our estimates. The Arellano-Bover/Blundell-Bond estimator is also referred to as the A-B-B estimator. GMM is generally used to study the dynamics of adjustment using samples with a short-time period and a relatively large cross-section.

Consider Equation (1) in Section 4: this includes as one of its regressors the lagged level of DI. The presence of a lagged dependent variable would yield seriously biased estimates because estimation with the conventional Ordinary Least Square (OLS) would lead to auto-correlation. Using OLS would bias the coefficient of the lagged term upwards, while using fixed effects would cause a downward bias in the aforementioned. In addition, the estimates would also be biased because the unobserved industry-specific effects may be correlated with the regressors. Finally, the inclusion of OFDI and IFDI would also raise the endogeneity issues due to the presence of potential bi-directional causality between OFDI and DI as well as between IFDI and DI.

To overcome these problems, Arellano and Bond (A-B) (1991) propose a first difference A-B GMM estimator, one advantage being that the lagged dependent variable and the endogenous regressors can also be instrumented using its lagged levels. The other advantage is that it also eliminates the problem of fixed country specific effects by taking the first differences of Equation (1) thereby eliminating the individual specific effects as shown in Equation (3) below.

$$
\begin{gathered}
D I_{i, t}-D I_{i, t-1}=\alpha_{1}\left(D I_{i, t-1}-D I_{i, t-2}\right)+\alpha_{2}\left(O F D I_{i, t}-O F D I_{i, t-1}\right)+\alpha_{3}\left(I F D I_{i, t}-\right. \\
\left.I F D I_{i, t-1}\right)+\alpha_{4}\left(G S_{i, t}-G S_{i, t-1}\right)+\beta^{\prime\left(x_{i, t}-x_{i, t-1}\right)\left(v_{i, t}-v_{i, t-1}\right)}+\varepsilon_{i, t} \cdots
\end{gathered}
$$


In Equation(3), given the assumption of no correlation between the regressand and the error terms and also between the regressors and the error terms, the minimum lag level of dependent variables must be two or greater.

A key limitation of the A-B estimator is that it does not necessarily eliminate firstorder serial correlation in the residuals. This is because the instruments used to control for endogeneity in the regressors are weakly exogenous. For this reason, in our study, we use the two-step system GMM or the A-B-B estimator to control for the weak instrument problem by using the level equation to obtain a system of two equations. The first equation includes instruments in first differences, while the second includes instruments in levels. By including the second equation, the variables in first differences are instruments for the variables in levels which increase efficiency. The use of the two step system GMM makes the standard covariance matrix robust to panel-specific autocorrelation and heteroskedasticity.

In the framework of the two-step system GMM, the Sargan test for over-identifying restrictions is used to assess for the validity of the instruments. The null hypothesis is that the instruments as a group are exogenous. The second order serial correlation in the difference error term is also tested where the null hypothesis is that there is no serial correlation.

\section{Data description}

Annual data for 14 Chinese industries are collected. The data span is 2004-2013 based on data availability ${ }^{4}$. All price indices have 2005 as the base year $(2005=100)$. Table 4 below presents summary statistics for the variables employed in our empirical analysis. The variables include Domestic Investment (DI), Outward FDI (OFDI), Inward FDI (IFDI), Government Support (GS), Growth Rate of Real Gross Industrial Product (RGIPG), Savings

\footnotetext{
${ }^{4}$ Note that the earliest annual data for China's OFDI data at industrial level is available only from 2004 from the Statistical Bulletin of China's Outward Foreign Direct Investment.
} 
(SAVINGS), Openness (OPENNESS), Supply of M2 (M2), Real Interest Rate (R), Financial Development (FD) and Country Risk (CR).

Table 4: Summary statistics

\begin{tabular}{|c|c|c|c|c|c|}
\hline Variables & $\begin{array}{c}\text { Number of } \\
\text { observations }\end{array}$ & Mean & $\begin{array}{c}\text { Standard } \\
\text { deviation }\end{array}$ & Min & \\
\hline DI & 154 & 62.764 & 71.195 & 8.301 & 334.65 \\
\hline OFDI & 154 & 1.526 & 4.158 & 0 & 26.894 \\
\hline IFDI & 154 & 1.928 & 2.328 & 0 & 93.463 \\
\hline GS & 154 & 43.680 & 27.003 & 0 & 39.182 \\
\hline RGIPG & 154 & 9.240 & 7.317 & -21.867 & 78.69 \\
\hline SAVINGS & 154 & 67.307 & 21.676 & 0 & 65.17 \\
\hline OPENNESS & 154 & 49.550 & 17.319 & 0 & 194.52 \\
\hline M2 & 154 & 154.926 & 51.133 & 0 & 3.49 \\
\hline R & 154 & 0.0760 & 1.791 & -3.07 & 162.963 \\
\hline FD & 154 & 128.37 & 42.307 & 0 & 57.381 \\
\hline
\end{tabular}

Data are at industrial level except the last six, for which industrial-level data are not available or are not feasible for our study. Note that variable Previous Domestic Investment is measured as the lag of domestic investment. Data employed to construct those variables are collected from various issues of the China Statistical Yearbook (CSY), except OFDI, which involves data collected from the Statistical Bulletin of China's Outward Foreign Direct Investment (SBCOFDI) and International Financial Statistics (IFS) and R, FS and CR, which involve data collected from IFS. Similar to Al-Sadig (2013), the dependent variable, DI, is measured as domestic investment of each industry divided by Gross Industrial Product (GIP). OFDI and IFDI are also measured as the ratio of industrial outward and inward FDI, respectively, to GIP. Note that OFDI data is US Dollar (USD) is collected SBCOFDI and is 
converted to Chinese Yuan (CNY) using exchange rate provided by IFS. GS is measured as industrial fixed assets investment made by the central government divided by total fixed asset investment in that industry. RGIPG is the growth rate of real GIP with the real GIP as the nominal GIP adjusted by the GIP deflator. SAVINGS, OPENNESS and FD are defined as the ratio of household savings, sum of exports and imports, and domestic credit respectively, to Gross Domestic Product (GDP). Note that data on domestic credit is provided by IFS. M2 is the broad money supply. $\mathrm{R}$ is defined as the nominal discount rate minus consumer price index- (CPI) based inflation, both available from IFS. CR is measured as the ratio of net foreign assets to GDP. Variable measurement and data sources are further summarized in Appendix A.

\section{Empirical results}

In this section, we report and interpret the empirical results of the effects of OFDI and government support on China's domestic investment. In Table 5 we present the results of five empirical models, referred to as models (1) - (5), respectively.

Based on Equation (3), our core model specification consists of the previous year's DI, OFDI, IFDI and GS. As explained previously, in order to control for endogeneity between these variables and to reflect China's economic conditions, we also include a set of control variables. Initially we include two control variables, namely RGIPG and SAVINGS, given their overwhelmingly strong positive influence on DI found in previous empirical studies (see Section 4) and in the recent developing countries study by Al-Sadig (2013). Indeed we found that both control variables were highly significant at the initial stage, although in contrast to our expectation that RGIPG exhibited a negative sign. We then added the control variables OPENNESS, M2, R, FD and CR, one at a time, with results as shown in columns (1)-(5) in Table 5, respectively. 
Table 5. Empirical results using the full sample (14 industries during the period 20042013)

\begin{tabular}{|c|c|c|c|c|c|}
\hline \multicolumn{6}{|c|}{ Dependent variable: Domestic Investment (DI) } \\
\hline Independent variables & (1) & (2) & (3) & (4) & (5) \\
\hline Lag of DI & $\begin{array}{c}0.848^{* * *} \\
(9.07)\end{array}$ & $\begin{array}{c}0.856^{* * *} \\
(9.21)\end{array}$ & $\begin{array}{c}0.853^{* * *} \\
(6.38)\end{array}$ & $\begin{array}{c}0.852^{* * *} \\
(9.13)\end{array}$ & $\begin{array}{c}0.846^{* * *} \\
(9.23)\end{array}$ \\
\hline OFDI & $\begin{array}{c}1.799 * * \\
(2.46)\end{array}$ & $\begin{array}{c}1.762^{* *} \\
(2.38)\end{array}$ & $\begin{array}{c}1.724 * * \\
(2.04)\end{array}$ & $\begin{array}{c}1.826^{* * *} \\
(2.62)\end{array}$ & $\begin{array}{l}1,781^{* *} \\
(2.46)\end{array}$ \\
\hline IFDI & $\begin{array}{l}3.373^{*} \\
(1.73)\end{array}$ & $\begin{array}{l}3.371^{*} \\
(1.85)\end{array}$ & $\begin{array}{l}3.406^{*} \\
(1.80)\end{array}$ & $\begin{array}{l}3.363^{*} \\
(1.75)\end{array}$ & $\begin{array}{l}3.377^{*} \\
(1.75)\end{array}$ \\
\hline GS & $\begin{array}{l}0.437^{*} \\
(2.28)\end{array}$ & $\begin{array}{l}0.436 * \\
(1.88)\end{array}$ & $\begin{array}{c}0.438 * * \\
(2.31)\end{array}$ & $\begin{array}{c}0.424 * * \\
(1.96)\end{array}$ & $\begin{array}{l}0.441^{*} \\
(1.86)\end{array}$ \\
\hline SAVINGS & $\begin{array}{c}0.675^{* * *} \\
(2.82)\end{array}$ & $\begin{array}{c}0.635^{*} \\
(2.09)\end{array}$ & $\begin{array}{l}0.698 \\
(1.49)\end{array}$ & $\begin{array}{c}0.705^{* *} \\
(2.54)\end{array}$ & $\begin{array}{c}0.662 * * \\
(2.50)\end{array}$ \\
\hline RGIPG & $\begin{array}{c}-3.651 * * * \\
(-4.19)\end{array}$ & $\begin{array}{c}-3.625 * * * \\
(-4.23)\end{array}$ & $\begin{array}{c}-3.643 * * * \\
(-3.39)\end{array}$ & $\begin{array}{c}-3.663 * * * \\
(-4.25)\end{array}$ & $\begin{array}{c}-3.72 * * * \\
(-3.85)\end{array}$ \\
\hline OPENNESS & $\begin{array}{l}-0.010 \\
(-0.05)\end{array}$ & & & & \\
\hline M2 & & $\begin{array}{l}-0.004 \\
(-0.02)\end{array}$ & & & \\
\hline $\mathrm{R}$ & & & $\begin{array}{l}-0.003 \\
(-0.00)\end{array}$ & & \\
\hline FD & & & & $\begin{array}{l}-0.020 \\
(-0.12)\end{array}$ & \\
\hline CR & & & & & $\begin{array}{l}0.042 \\
(0.09)\end{array}$ \\
\hline Intercept & $\begin{array}{c}-34.714 \\
(-1.37)\end{array}$ & $\begin{array}{c}-36.606 \\
(-1.63)\end{array}$ & $\begin{array}{c}-37.525 \\
(-1.24)\end{array}$ & $\begin{array}{l}-34.104 \\
(-1.36)\end{array}$ & $\begin{array}{c}-35.814 \\
(-1.41)\end{array}$ \\
\hline $\mathrm{N}$ & 139 & 139 & 138 & 139 & 139 \\
\hline Number of sectors & 14 & 14 & 14 & 14 & 14 \\
\hline ar1 (p-value) & 0.022 & 0.029 & 0.048 & 0.029 & 0.032 \\
\hline ar2 (p-value) & 0.507 & 0.508 & 0.532 & 0.508 & 0.526 \\
\hline Sargan tests (p-value) & 0.992 & 0.993 & 0.988 & 0.994 & 0.992 \\
\hline $\begin{array}{l}\text { Difference in Hansen tests } \\
\text { (p-value) }\end{array}$ & 0.954 & 0.987 & 0.957 & 0.999 & 0.968 \\
\hline
\end{tabular}

Note: System-GMM is employed for the estimation. The t-stats are in brackets. * ${ }^{* *}$ and $* * *$ indicate $10 \%, 5 \%$ and $1 \%$ significance level respectively. ar1 and ar2 are tests for $1^{\text {st }}$ and $2^{\text {nd }}$ order serial correlation respectively. 
Across columns (1)-(5), our first observation is that, in all cases, OFDI and GS have consistently positive and significant impacts on domestic investment. Specifically, at 5\% significance level, a $1 \%$ increase in OFDI leads to an increase in domestic investment in the range of $1.72 \%-1.83 \%$. Similarly, at $10 \%$ significance level, a $1 \%$ increase in GS implies domestic investment would increase by approximately $0.44 \%$. We now explain our findings regarding these two variables in detail.

Regarding OFDI in Table 5, a 1\% increase in OFDI leads to an increase in domestic investment of 1.80\% in Model 1, 1.76\% in Model 2, 1.72\% in Model 3 and 1.78\% in Model 5. In Model 4, OFDI has the largest and most significant impact on DI. A 1\% increase in OFDI causes DI to expand by $1.83 \%$ and it is significant at the $1 \%$ level. These results are interesting, as they confirm that Chinese domestic investment seems to respond positively to overseas investment at the industrial level. OFDI can increase DI through the two mechanisms discussed in Section 3. The first operates via the financial market, as OFDI would direct domestic savings abroad and would leave fewer financial resources for domestic firms. However, this rationale may have limited implications for China. Firstly, the savings pool in China, which has the highest savings ratio of all major economies, may well be larger than domestic investment financing demands. In addition, the accumulation of vast FX reserves over the past decade, combined with the "going out" policy advocated by the central government, would indicate that China's OFDI relies heavily on FX reserves rather than domestic savings, and hence may not necessarily impose a significant threat to domestic investment. The second mechanism involves the product markets, where various motives for OFDI would lead to different impacts on domestic investment. As Cheung and Qian (2009) show, China’s OFDI is mainly driven by market- and resource-seeking motives. Section 3 explains that, while resources-seeking motive implies a positive impact of OFDI on domestic investment, the market-seeking motive could imply a negative, neutral, or positive impact, 
depending on the balance between the exports promoting and the exports substituting effect of overseas investment. The positive coefficient of OFDI found in our analysis probably suggests that the exports substituting effect is in fact relatively small. Thus, we observe positive signs of OFDI across all cases.

Another main finding revealed by Table 5 is that government support (GS) has a significantly positive impact on China's domestic investment. This result is highly consistent across Models (1)-(5) that a 1\% increase in OFDI leads to an increase in domestic investment of $1.44 \%$, except for a slightly lower ratio of 1.42 per cent in Model 4 . This first demonstrates that the level of government support is an important feature that needs to be taken into account in order to better understand China's domestic investment at industrial level. More importantly, it confirms that Chinese industries with higher levels of government support do enjoy significant economic advantages and favorable policies to make more domestic investment.

We now investigate other two core variables, DI and IFDI. DI in previous years is positive and significant in all Models (Table 5). A 1\% increase in DI in the previous year leads to an increase of approximately $0.85 \%$ in the current one, showing that the relationship between current and previous investment can be explained by the flexible accelerator model. We also found that IFDI has a positive and significant impact on domestic investment in China at the $10 \%$ level. All Models suggest that an increase in IFDI of $1 \%$ leads to an increase in DI of approximately 3.4\%. Thus, similar to Xu and Wang (2007), our study finds that China’s IFDI crowds in industrial domestic investment.

In terms of control variables, RGIPG was found to be negative and significant at the $1 \%$ level in all five models. An increase in RGIPG leads to a decrease in DI of approximately 3.6\%. The results contrast with our a priori expectation of a positive relationship between RGIPG and DI. Although high economic growth may encourage domestic investment, in the 
case of China a higher industrial growth rate may also be a reflection of over-investment, especially given the economy's excessive reliance on investment and abundant domestic savings. Hence a negative sign of RGIPG probably implies that divestment rather than more investment is actually needed for a healthier and more sustainable growth model for China. SAVINGS is significant at the $10 \%$ level in Model 1 and at the 5\% level in Models 2, 4 and 5 where a $1 \%$ increase in SAVINGS leads to an increase in DI of about $0.7 \%$. The only exception is in Model 3, where the coefficient is positive but insignificant. Our results suggest that domestic investment responds positively to domestic savings in most cases. No other control variable turned out to be significant, which implies that China's domestic investment is not responsive to the level of openness, money supply, cost of capital (real interest rate), financial development or country risk.

The Sargan tests and serial correlation tests are reported at the bottom of Table 5. Across all five cases the Sargan tests suggest that the null hypothesis of the validity of instruments cannot be rejected. The serial correlation tests imply that there are first-order serial correlations, which is often expected, but no evidence of second-order serial correlation in the differenced error terms. As an alternative to the Sargan test, we also report the difference in Hansen tests to check the validity of each subset of instruments. Again, in no case do the Hansen tests reject the null hypothesis of the joint validity of all the instruments ${ }^{5}$.

\section{Further analysis of the role of government support}

We previously investigated how OFDI affects domestic investment whilst taking into account the role of the government support for the whole sample. We found overwhelming evidence that government support has a significant and positive impact on domestic investment in

\footnotetext{
${ }^{5}$ While a higher p-value of the Sargan test suggests stronger rejection of the null hypothesis, an excessively high p-value may also indicate the employment of too many instruments. We thus include the alternative Hansen test to confirm the results of the Sargan test. However, it should be noted that Roodman (2009) states that the Sargan tests in comparison to the Hansen tests for over-identification is not so vulnerable to the problem of too many instruments.
} 
China. In this section, we further examine how government support influences the mechanisms through which OFDI affects domestic investment in China. To do so, we divide our sample into two sub-samples according to the level of government support in each industry, and investigate whether domestic investment responds to OFDI differently in statedominated industries compared with non-state-dominated ones. We calculate the median state ownership for our whole sample, obtaining a ratio of $50 \%$. Table 5 shows that seven of the 14 industries average higher than the median value of 50\%. We thus refer to industries with more than 50\% government ownership as "state-dominated industries", with the other sectors being denominated "non-state-dominated industries". 
Table 6. Dividing industries according to the level of government support

\begin{tabular}{|c|c|}
\hline $\begin{array}{c}\text { State-dominated industries } \\
\text { (Government ownership }>50 \% \text { ) }\end{array}$ & $\begin{array}{l}\text { Non-state-dominated industries } \\
\text { (Government ownership }<50 \% \text { ) }\end{array}$ \\
\hline Construction & Agriculture, forestry, animal husbandry and fishery \\
\hline Culture, sports and entertainment & Leasing and business services \\
\hline $\begin{array}{c}\text { Information transmission, computer services and } \\
\text { software }\end{array}$ & Lodging and catering services \\
\hline Mining & Manufacturing \\
\hline $\begin{array}{l}\text { Production and supply of electricity, heat and } \\
\text { water }\end{array}$ & Real estate \\
\hline $\begin{array}{l}\text { Scientific research, technical services and } \\
\text { geological prospecting }\end{array}$ & Services to households and other services \\
\hline Transport, storage and post & Wholesale and retail trade \\
\hline
\end{tabular}

We next divide our sample as shown in Table 6 into state- and non-state-dominated industries and re-estimated Equation (3) using system GMM. Based on the results of Table 5, the estimations were carried out using the determinants and the control variables that were consistently significant, namely domestic investment (DI), outward foreign direct investment (OFDI), inward foreign direct investment (IFDI) and the growth rate of real industrial product (RGIPG).

Table 7 reports the results for the split samples. The results are shown in columns (1) for state-dominated industries and (2) for non-state-dominated ones. In both cases, OFDI has a significant positive impact on DI, which is consistent with the full sample results in Table 5. However, one interesting finding that has emerged after we divided our sample according to the level of government ownership is that the coefficient of OFDI for state-dominated industries (24.803) is much higher than that of non-state-dominated ones (0.846). A $1 \%$ increase in OFDI increases DI by $24.8 \%$ for the former, but by less than $1 \%$ for the latter. Our results suggest that the impact of OFDI on DI is amplified for industries that benefit from huge government support. The significant impact of Chinese OFDI on DI for state dominated industries proves that most outward investment activities are directed by the Chinese 
government. These outward investment activities are mainly in oil and minerals and in telecommunications, but also include IT, construction, and power generation and distribution (Salidjanova, 2011). These investments are consequently likely to have a huge multiplier effect on domestic investment of state-dominated industries. 
Table 7. Empirical results for state-dominated and non-state-dominated industries (2004-2013)

\begin{tabular}{|c|c|c|}
\hline $\begin{array}{c}\text { Dependent variable: } \\
\text { Domestic Investment (DI) }\end{array}$ & $\begin{array}{c}\text { State dominated } \\
\text { industries } \\
\text { (Government } \\
\text { ownership > 50\%) }\end{array}$ & $\begin{array}{c}\text { Non-state-dominated } \\
\text { industries } \\
\text { (Government } \\
\text { ownership < 50\%) }\end{array}$ \\
\hline Lag of DI & $\begin{array}{c}0.882 * * * \\
(2.73)\end{array}$ & $\begin{array}{l}0.422 * \\
(1.68)\end{array}$ \\
\hline OFDI & $\begin{array}{c}24.803^{* * *} \\
(3.45)\end{array}$ & $\begin{array}{l}0.846^{*} \\
(1.81)\end{array}$ \\
\hline IFDI & $\begin{array}{l}37.828 \\
(1.16)\end{array}$ & $\begin{array}{c}-7.649 * * \\
(-2.24)\end{array}$ \\
\hline RGIPG & $\begin{array}{l}-1.619 \\
(-0.67)\end{array}$ & $\begin{array}{c}-0.792 * * * \\
(-2.87)\end{array}$ \\
\hline Intercept & - & $\begin{array}{c}83.168^{* * *} \\
(2.56)\end{array}$ \\
\hline $\mathrm{N}$ & 70 & 70 \\
\hline Number of sectors & 7 & 7 \\
\hline ar1 (p-value) & 0.000 & 0.001 \\
\hline ar2 (p-value) & 0.697 & 0.236 \\
\hline Sargan tests (p-value) & 0.720 & 0.671 \\
\hline $\begin{array}{l}\text { Difference in Hansen tests (p- } \\
\text { value) }\end{array}$ & 0.418 & 0.772 \\
\hline
\end{tabular}

Note: See Note at Table 5.

This finding suggests that the level of government support indeed affects the two mechanisms through which OFDI influences domestic investment. Recall that the first mechanism operates through domestic financial markets, where OFDI would drain the domestic savings pool, leaving fewer financial resources available to domestic investment. As discussed earlier, the huge FX reserves accumulated in the past decade have been deployed to become important sources of China's overseas investment, resulting in alleviation of this negative impact. More importantly, SOEs in China enjoy more financial support from the source of FX reserves than non-SOEs when expanding abroad (Wei and 
Alon, 2011). Therefore, OFDI from state-dominated industries would have a far smaller or even negligible negative impact on domestic investment compared with their non-statedominated counterparts.

The second mechanism features product markets where the motives for OFDI determine how it affects domestic investment. Table 6 shows state-dominated industries including ones that use natural resources (e.g., mining, electricity production and supply, and heat and water) and technological capability (e.g. information transmission, computer services and software, scientific research, technical services and geological prospecting) abroad, whose OFDI motive can be largely described as resource-seeking ${ }^{6}$. On the other hand, non-state-dominated industries in China include manufacturing and services industries (e.g., leasing and business services, lodging and catering services, services to households and other services) whose OFDI motives as described by Amighini et al. (2011) are more geared towards market-seeking and strategic asset-seeking. Empirical findings by Amighini et al. (2012) further confirm that Chinese SOEs are resource- and strategic asset-seekers whilst private firms are market- and strategic asset-seekers. Since state- and non-state-dominated industries' motives for OFDI differ, that OFDI would have different impacts on domestic investment. The larger coefficient of the state-dominated industries is likely to be a reflection of the resource-seeking nature of these industries' OFDI, which would stimulate domestic investment without reducing exports. On the other hand, non-state dominated industries' smaller coefficient captures their OFDI's market-seeking motive, which has a much lower positive impact on domestic investment, since this type of OFDI may to some extent replace exports or shift domestic production abroad.

We also observe that RGIPG and IFDI both have a negative and significant impact on DI for non-state dominated industries. However, for state dominated industries, the impact of

\footnotetext{
${ }^{6}$ For instance, Amighini et al. (2011) find that resource-seeking is an important motive for resource-related industries.
} 
both these variables is insignificant. The robustness tests show that we do not reject the null hypothesis of the joint validity of the instruments, as shown by the Sargan tests and differences in Hansen tests respectively. A first order serial correlation exists, but there is no evidence of second order serial correlation.

\section{Conclusions and policy implications}

Encouraged by the national policy of Chinese firms "going out", and facilitated by vast FX reserves, China has engaged in rapid overseas expansion in the past decade. At the same time, China's domestic economic growth continues to rely on the accumulation of domestic investment instead of consumption. Our study therefore asks how China's domestic investment responds to FDI outflows. Despite its importance to China's growth path and its policymakers, we find that empirical investigation on this issue for China is very rare.

Our study provides the first empirical examination of OFDI's impact on China's domestic investment using a new industrial perspective. To capture the role played by the Chinese state, we specifically account for the factor of government support in our analysis. Our estimates using system-GMM suggest that outward FDI has a positive influence on domestic investment. Linking this finding to relevant theoretical mechanisms through which OFDI affects domestic investment (namely, the financial market channel and the product market channel), this positive impact can be attributed to China's abundant domestic savings, vast FX reserves and the particular motives of its OFDI, such as resource- and marketseeking. We also find that more government support leads to higher domestic investment in China’s industries, confirming the important role played by the state.

We then further evaluate whether domestic investment's reaction to outward FDI differs between state-dominated and non-state-dominated industries. Our results show that OFDI has a much stronger influence on domestic investment in the former. It suggests that 
FX reserves are much more easily accessed by the state-dominated industries to make overseas investment than by non-state dominated industries, and hence that OFDI relies even less on domestic savings. It also highlights that the motive for foreign expansion of statedominated industries is mainly resource-seeking, whilst that of their non-state dominated counterparts is mainly market-seeking.

Given the positive impact China’s OFDI has on its domestic investment, it seems that Chinese industries' overseas expansion may have the unintended result of making the Chinese economy even more reliant on domestic investment. OFDI's crowding in impact on domestic investment implies that switching the Chinese economy to a more sustainable consumption-led growth path would need to be driven by other methods such as developing the medical and pension system to reduce the propensity to savings, developing financial markets to provide opportunities for future income to be used to smooth current consumption, and encouraging technological innovation in order to increase productivity.

Our results also highlight that state involvement has a significant and positive impact on domestic investment. Many studies suggest that Chinese SOEs are inefficient in terms of profits, productivity and growth (e.g., Dougherty et al., 2007; Zhang, 2004), yet they are often the ones that enjoy low cost financial resources and preferential government policies. The state must continue to deepen its privatization and reform process regarding SOEs so as to increase their efficiency and thus reduce their ineffective consumption of domestic investment.

Furthermore, our results suggest that industries with different levels of government support tend to have different motives for investing abroad. Although both crowd in domestic investment, OFDI from state-dominated industries has a much stronger positive impact on domestic investment compared with non-state-dominated ones, as the former tend to be market-seekers while the latter are resource-seekers by nature. Further privatization and 
reform of SOEs should therefore be prioritized for sectors with higher levels of state dominance, not only because they are more inefficient, but also because their OFDI crowd in more domestic investment. 


\section{References}

Agènor, P., 2004, The economics of adjustment and growth, second edition, Harvard University Press.

Al-Sadig, A., 2013, "Outward foreign direct investment and domestic investment: The case of developing countries, IMF Working Paper, WP/13/52.

Arellano, M. and Bond, S., 1991, "Some tests of specification for panel data: Monte Carlo evidence and an application to employment equations”, The Review of Economic Studies, 58, 277-97.

Arellano, M. and Bover, O., 1995, "Another look at the instrumental variable estimation of error-components models,” Journal of Econometrics, 68, 29-51.

Amighini, A., Rabellotti, R., and Sanfilippo, M., 2011, “China’s outward FDI: An industrylevel analysis of host country determinants”, CESifo Working Paper Series, No. 3688.

Amighini, A., Rabellotti R., and Sanfilippo, M., 2012, "Do Chinese SOEs and private companies differ in their foreign location strategies?” RSCAS Working Paper, 2012/27, European University Institute.

Arndt, C., Buch, C. and Schnitzer, M., 2007, "FDI and domestic investment: An industrylevel view”, CEPR Discussion Papers, 6464.

Blejer, M. and Khan M., 1984, "Government policy and private investment in developing countries”, IMF Staff Papers, 31(2), 379-403.

Blundell, R. and Bond, S., 1998, "Initial conditions and moment restrictions in dynamic panel data models”, Journal of Econometrics, 87, 114-43.

Braunerhjelm, P., Oxelheim, L. and Thulin. P., 2005, “The relationship between domestic and outward foreign direct investment: The role of industry-specific effects”, International Business Review, 14(6), 677-94.

Braunstein, E. and Epstein, G., 2002, "Bargaining power and foreign direct investment in China: Can 1.3 billion consumers tame the multinationals?” CEPA Working Paper 2002/13. New York: Centre for Economic Policy Analysis.

Buckley P. and Ghauri P. eds., 1999, “The Internationalization of the firm. A reader”, 2nd ed., International Thomson Business Press, London.

Cheung, Y. W. and Qian, X. W., 2009, “The empirics of China’s outward direct investment”, CESifo Working Paper Series, No. 2621.

Child, J. and Rodriguez, S. B., 2005, “The Internationalization of Chinese firms: A case for theoretical extension?”, Management and Organization Review, 1(3), 381-410.

Choy, L., Ho, W. and Mak, S., 2009, “On FDI and domestic capital stock: A panel data study of Chinese regions”, Building and Real Estate Workshop Paper, The Hong Kong Polytechnic University. 
Desai, M. A., Foley, C. F. and Hines. J. R., 2005, "Foreign direct investment and the domestic capital stock”, American Economic Review, 95(2), 33-8.

Dougherty, S, Herd, R., and He, P. 2007, “Has a private sector emerged in China's industry? Evidence from a quarter of a million Chinese firms", China Economic Review, 18, 309-34.

Dunning, J., 1993, Multinational Enterprises and the Global Economy, Cheltenham, UK: Edward Elgar Publishing.

Feldstein, M., and Horioka, C., 1980, “Domestic savings and international capital flows”, Economic Journal, 90, 314-329.

Goh, S. K. and Wong K. N., 2012, “Outward FDI and domestic investment”, International Proceedings of Economics Development and Research, 55.27, 137-140.

Greene, J., and Villanueva, D., 1991, "Private investment in developing countries”, IMF Staff Papers, 38(1), 33-58, Washington: International Monetary Fund.

Greenwood, J. and Hercowitz, Z., 1991, "The allocation of capital and time over the business cycle”, Journal of Political Economy, 99(6), 1188-214.

Hejazi, W., and Pauly, P., 2003, "Motivations for FDI and domestic capital formation", Journal of International Business Studies, 34, 282-89.

Hong, E. and Sun L., 2006, "Dynamics of internationalization and outward investment: Chinese corporations' strategies”, The China Quarterly, 187, 610-34.

Jin, J. C., 2004, “On the relationship between openness and growth in China: Evidence from provincial time series data”, The World Economy, 27, 1571-82.

Jorgenson, D. W., 1963, “Capital Theory and Investment Behaviour”, American Economic Review, 53(2), 247-259.

Jorgenson, D. W., 1996, Investment: Tax policy and the cost of capital. MIT press, U.S.

Kim, S., 2000, "Effect of outward foreign direct investment on home country performance: Evidence from Korea”, in: The Role of Foreign Direct Investment in East Asian Economic Development, NBER-EASE Volume 9, 295-317, National Bureau of Economic Research, Inc.

King, R. G. and Plosser, C. I., 1984, "Money, credit and prices in a real business cycle”, American Economic Review, 74(3), 363-80.

Kollintzas, T., Konstantakopoulou, I. and Tsionas, E., 2011, "Stylized facts of money and credit over the business cycles”, Applied Financial Economics, 21, 1735-55.

Lee, I. H., Syed, M. and Liu X., 2013, “China’s path to consumer-based growth: Reorienting investment and enhancing efficiency”, IMF Working Paper, WP/13/83 
Levine, R., 2004, “Finance and growth: Theory and evidence”, NBER Working Paper Series, 10766.

Luo, Y., Xue Q. and Han, B., 2010, "How emerging market governments promote outward FDI: Experience from China”, Journal of World Business, 45(1), 68-79.

Morrison, W. M., 2014, “China’s economic rise: History, trends, challenges, and implications for the United States”, Congressional Research Service, 7-5700.

Roodman, D., 2009, "Practitioner's corner: A note on the theme of too many instruments", Oxford Bulletin of Economics and Statistics, 7(1), 135-58.

Stevens, G. V. G. and Lipsey, R. E., 1992, "Interactions between domestic and foreign investment”, Journal of International Money and Finance, 11(1), 40-62.

Sermcheep, S., 2013, "Foreign direct investment and economic growth: The case of Thailand's inward and outward FDI", paper presented at the Asia-Pacific Economic Association Ninth Annual Conference, Osaka, July 27-28, 2013

Temperton, P., 2012, September 20 “A country’s wealth is useful indicator”, Financial Times. Retrieved from http://www.ft.com/cms/s/0/73164654-0183-11e2-81ba-00144feabdc0.html. 2012, September 20.

UNCTAD, 2006, World Investment Report, United Nations, New York and Geneva.

Salidjanova, N. 2011, Going-Out: An Overview of China's Outward Foreign Direct Investment, March 2011, USCC Staff Research Report. Retrieved from http://www.uscc.gov/sites/default/files/Research/GoingOut.pdf

Wang, C., Hong, J., Kafouros, M., and Boateng, A., 2012, "What drives outward FDI of Chinese firms? Testing the explanatory power of three theoretical frameworks", International Business Review, 21(3), 425-38.

Warner, M., Hong, N.S. and Xu, X., 2004, "Late development experience and the evolution of transnational firms in the People's Republic of China”, Asia Pacific Business Review, 10(3-4), 324-45.

Wei, W. X., and Alon, I., 2010, "Chinese outward direct investment: a study on macroeconomic Determinants", International Journal of Business and Emerging Markets, 2(4), 352-68.

Wu, H., 2008, “An empirical study on the macro performance of Chinese FDI - based on the foreign currency reserve”, Science and Technology Progress and Policy, 25(12).

Xu, G. and Wang, R., 2007, “The Effect of foreign direct investment on domestic capital formation, trade and economic growth in a transition economy: Evidence from China”, Global Economy Journal, 7(2), 1-21.

Yusuf, S., 1994, “China’s macroeconomic performance and management during transition”. Journal of Economic Perspectives, 8(2), 71-92. 
Zhang, L., 2004, “The roles of corporatization and stock market listing in reforming China's state Industry”, World Development, 32(12), 2031-47.

Zhang, Y. and Wan G., 2005, “China’s business cycles: Perspectives from AD-AS model”. Asian Economic Journal, 19(4), 445-69.

\section{Highlights:}

- We examine how domestic investment responds to outward FDI in Chinese industries.

- We account for the role of government support, and adopt the system-GMM to estimate.

- Domestic investment responds positively to outward FDI in China.

- The level of government support affects how outward FDI influences domestic investment.

- Domestic investment reacts more strongly to outward FDI in state-dominated industries. 